\title{
PROGRAM PDS BERKELANJUTAN DALAM PEMBELAJARAN SINTAKSIS BAHASA INDONESIA BERBASIS KKNI DI STKIP MUHAMMADIYAH KOTABUMI
}

\author{
Nur Mei Ningsih *) \\ nurmeiningsih02@gmail.com \\ Pendidikan Bahasa dan Sastra Indonesia \\ Universitas Muhammadiyah Kotabumi
}

\begin{abstract}
Program Penugasan Dosen di Sekolah (PDS) gives experience for the lecturers to understand comprehensively students' characteristics in learning process. The learning process applied at STKIP Muhammadiyah Kotabumi based on KKNIDikti based curriculum with the characteristics which are interactive, holistic, integrative, saintific, contextual, them atic, collaborative, and student-centered. Indonesian syntax course focused on the students or how the students learn and understand the concept of material as well as implement it based on the concept understood. The method used in this article is descriptive method and qualitative approach in which describing the condition of fourth semester students in Indonesian syntax course. Based on the finding it was found that $88 \%$ students were active, creative and enthusiastic in learning process because the method and learning model are varied. It made the students to be more interested and active in following the learning. Meanwhile, $12 \%$ students were active and motivated to learn. It can be concluded that the sudents' achievement was increased.
\end{abstract}

Key Words : Learning Process, Learning System, PDS

\section{PENDAHULUAN}

Kegiatan Penugasan Dosen di Sekolah merupakan kegiatan yang memberikan dampak positif baik bagi perguruan tinggi maupun bagi pihak sekolah mitra. Program Penugasan Dosen di Sekolah membutuhkan komitmen dosen untuk mengalami dan menjadi guru di sekolah mitra. Kegiatan Penugasan Dosen di sekolah bermitra dengan Sekolah Dasar Negeri 04 kotabumi sudah terlaksana dan tindak lanjut kegiatan PDS dilakukan di perguruan tinggi Sekolah Tinggi Keguruan dan Ilmu Pendidikan Muhammadiyah Kotabumi. Program Penugasan Dosen di Sekolah mengandung multifungsi dalam peningkatan kualitas guru dan dosen yang profesional. Lembaga Pendidikan Tinggi ke sekolah mitra terkait dengan pesatnya perkembangan ilmu pendidikan dan teoriteori belajar, memfasilitasi dosen untuk menghayati secara langsung menjadi "guru" di sekolah mitra. Hasil dari pelaksanakan 
kegiatan PDS di sekolah tersebut diimplementasikan di perguruan tinggi. Proses pembelajaran yang dilaksanakan di perguruan tinggi menggunakan kurikulum Kerangka Kualifikasi Nasional Indonesia (KKNI) Standar Nasional Pendidikan Tinggi atau SN-Dikti.

Kurikulum Pendidikan Tinggi (KPT) adalah seperangkat rencana dan pengaturan mengenai capaian pembelajaran lulusan, bahan kajian, proses, dan penilaian yang digunakan sebagai pedoman penyelenggaraan kegiatan pembelajaran di perguruan tinggi. Kurikulum harus memuat capaian pembelajaran yang mengacu pada deskripsi level 6 (enam) Kerangka Kualifikasi Nasional Indonesia (KKNI) sesuai Perpres Nomor 8 Tahun 2012 dan Permenristekdikti No. 44 Tahun 2015 tentang Standar Nasional Pendidikan Tinggi (SN-Dikti), yang terstruktur untuk tercapainya tujuan, terlaksananya misi, dan terwujudnya visi keilmuan program studi.

Sistem pembelajaran yang dilaksanakan di STKIP Muhammmadiyah Kotabumi berdasarkan pada kurikulum tersebut dengan sistem pembelajaran yang berkarakteristik interaktif, holistik, integratif, saintifik, kontektual, tematik, kolaboratif, dan berpusat pada mahasiswa. https://Suadinmath.wordspress.com/2013/0 2/09/Pentingnya Pembelajaran Menyenangkan dalam Peningkatan Mutu Proses dan Hasil Belajar
Interaktif diartikan bahwa capaian pembelajaran lulusan diraih dengan mengutamakan proses interaksi dua arah antara mahasiswa dan dosen. Holistik mencerminkan bahwa proses pembelajaran mendorong terbentuknya pola pikir yang komprehensif dan luas dengan menginternalisasi keunggulan dan kearifan lokal maupun nasional.

Integratif menunjukkan bahwa capaian pembelajaran lulusan diraih melalui proses pembelajaran yang terintegrasi untuk memenuhi capaian pembelajaran lulusan secara keseluruhan dalam satu kesatuan program melalui pendekatan antardisiplin dan multidisiplin. Saintifik dimaknai bahwa capaian pembelajaran lulusan diraih melalui proses pembelajaran yang mengutamakan pendekatan ilmiah sehingga tercipta lingkungan akademik yang berdasarkan sistem nilai, norma, dan kaidah ilmu pengetahuan serta menjunjung tinggi nilainilai agama dan kebangsaan.

Tematik berarti capaian pembelajaran lulusan diraih melalui proses pembelajaran yang disesuaikan dengan karakteristik keilmuan program studi dan dikaitkan dengan permasalahan nyata melalui pendekatan transdisiplin. Efektif menyatakan bahwa capaian pembelajaran lulusan diraih secara berhasil guna dengan mementingkan internalisasi materi secara baik dan benar dalam kurun waktu yang optimum. Kolaboratif adalah proses 
pembelajaran bersama yang melibatkan interaksi antar individu pembelajar untuk menghasilkan kapitalisasi sikap, pengetahuan, dan keterampilan dalam upaya meraih capaian pembelajaran. Berpusat pada mahasiswa menunjukkan bahwa capaian pembelajaran lulusan diraih melalui proses pembelajaran yang mengutamakan pengembangan kreativitas, kapasitas, kepribadian, dan kebutuhan mahasiswa, serta mengembangkan kemandirian dalam mencari dan menemukan pengetahuan.

Proses pembelajaran yang akan dilaksanakan di Perguruan tinggi Sekolah Tinggi Keguruan dan Ilmu pendidikan mata kuliah Sintaksis Bahasa Indonesia, banyak model pemabelajaran yang bervariasi. Model pembelajaran adalah kerangka konseptual yang digunakan sebagai pedoman dalam melakukan pembelajaran yang disusun secara sistematis untuk mencapai tujuan belajar yang menyangkut sintaksis, sistem sosial, prinsip reaksi dan sistem pendukung (Joice dan Wells dalam Materi Pelatihan Implementasi Kurikulum 2013 tahun 2016, Kemendikbud). Menurut Djamarah (2008:22 ) dalam pembelajaran penemuan mengatur pengajaran sedemikian rupa sehingga anak memperoleh pengetahuan yang sebelumnya diketahui, tidak melalui pemberitaan, tetapi sebagian atau seluruhnya ditemukan sendiri. Model pembelajaran ini merupakan model pembelajaran yang berpusat pada peserta didik/mahasiswa sehingga dapat terbangun sikap aktif, kreatif, dan inovatif dalam diri peserta didik/mahasiswa.

Menurut bruner dalam Cahyo (201:251) agar pembelajaran berjalan dengan baik dan kreatif jika pendidik/dosen memberikan kesempatan kepada peserta didik/mahasiswa untuk menemukan suatu konsep, teori, aturan atau pemahaman melalui contoh-contoh yang dijumpai dalam kehidupannya.

Jadi dengan menggunakan metode dan model pembelajaran yang bervariasi akan membuat mahasiswa menjadi semangat dan termotivasi mengikuti pembelajaran terutama dalam mata kuliah Sintaksis Bahasa Indonesia Mata kuliah Sintaksis Bahasa Indonesia merupakan mata kuliah kebahasan yang membahas mengenai klausa dan kalimat, tetapi penekanan pembahasan materi lebih difokuskan pada kalimat. Jumlah SKS dalam Mata Kuliah Sintaksis Bahasa Indonesia adalah 3 SKS yang ada pada semester empat.

Kegiatan PDS pembelajaran Sintaksis Bahasa Indonesia dilaksanakan dalam tiga tahapan yakni Perencanaan (plan), Pelaksanaan (Do), dan Refleksi (See). Melalui kegiatan PDS, dosen mampu meningkatkan kualitas mengajar dengan memperhatikan karakteristik mahasiswa, mulai dari metode dan strategi, media, 
model pembelajaran yang sesuai dengan materi ajar dalam mata kuliah Sintaksis Bahasa Indonesia. Mata Kuliah Sintaksis Bahasa Indonesia bertujuan supaya mahasiswa memiliki penguasaan konsep dan mampu mengimplementasikan konsep yang dikuasai.

\section{METODE}

Metode yang digunakan adalah metode kualitatif dalam latar yang wajar (natural) dengan berupaya memahami dari apa yang diamati (Sentana, 2010:45). Metode ini juga disebut metode artistic (Sugiyono, 2011:7) karena proses bersifat seni (kurang terpola) dan disebut metode interpretative karena hasil berkenaan dengan interpretasi data yang dikumpulkan di lapangan. Metode yang digunakan dalam penyusunan artikel berdasarkan pengamatan langsung oleh dosen pengampu mata kuliah mengenai pembelajaran mata kuliah Sintaksis Bahasa Indonesia yang dilaksanakan dan melalui pengambilan gambar audio visual atau pandang dengar. Dosen akan mendiskripksikan atau menguraikan mengenai pelaksanaan pembelajaran yang dilaksanakan pada mahasiswa semester IV yang berjumlah 46 dalam mata kuliah Sintaksis Bahasa Indonesia STKIP Muhammadiyah Koabumi. Pengambilan data dilakukan dengan mengamati semua aktivitas mahasiswa dalam proses pembelajaran Sintaksis Bahasa Indonesia, mulai dari pertemuan awal sampai dengan pertemuan kedelapan.

\section{HASIL DAN PEMBAHASAN}

Pelaksanaan pembelajaran mata kuliah Sintaksis Bahasa Indonesia melalui program PDS pada mahasiswa semester empat sebanyak delapan kali pertemuan. Proses pelaksaan dilakukan dengan cara bertahap .Proses pelaksanaan pembelajaran di mulai dengan merencanakan RPS dan bahan ajar yang akan diajarkan, melaksanakan pembelajaran sesuai dengan RPS dan materi ajar yang sudah dibuat/disusun, melakukan refleksi dari hasil pelaksanaan pembelajaran, sampai dengan pemberian penilaian dalam proses pembelajaran tersebut. Dalam artikel ini akan dideskripsikan seluruh kegiatan pembelajaran Sintaksis Bahasa Indonesia pada mahasiswa semester IV.

Pembelajaran dimulai dari plan, Do, dan See, seperti yang dikemukakan oleh Susilo (2011:35) dalam pembelajaran meliputi 3 tahap: tahap Perencanaan (Plan), tahap pelaksanaan (Do), tahap pengamatan dan refleksi (See). Hendayana (2006:10) menegaskan bahwa setiap guru berkesempatan untuk melakukan hal-hal berikut dalam proses pembelajaran. 
1. Mengidentifikasi masalah pembelajaran

2. Mengkaji pengalaman pembelajaran yang dilakukan

3. Memilih alternatif model pembelajaran yang digunakan

4. Merancang Rencana Pembelajaran

5. Melaksanakan Pembelajaran

6. Mengobservasi pelaksanaan pembelajaran
8. jar siswa di kelas

9. Melakukan Refleksi setelah melakukan proses pembelajaran

10. Mengambil pelajaran berharga dari setiap kegiatan pembelajaran Seperti yang terlihat dalam siklus pengkajian pembelajaran dilaksanakan dalam tiga tahap, seperti dalam Gambar berikut ini.

7. Mengidentifikasi hal-hal penting mengenai aktivitas bela

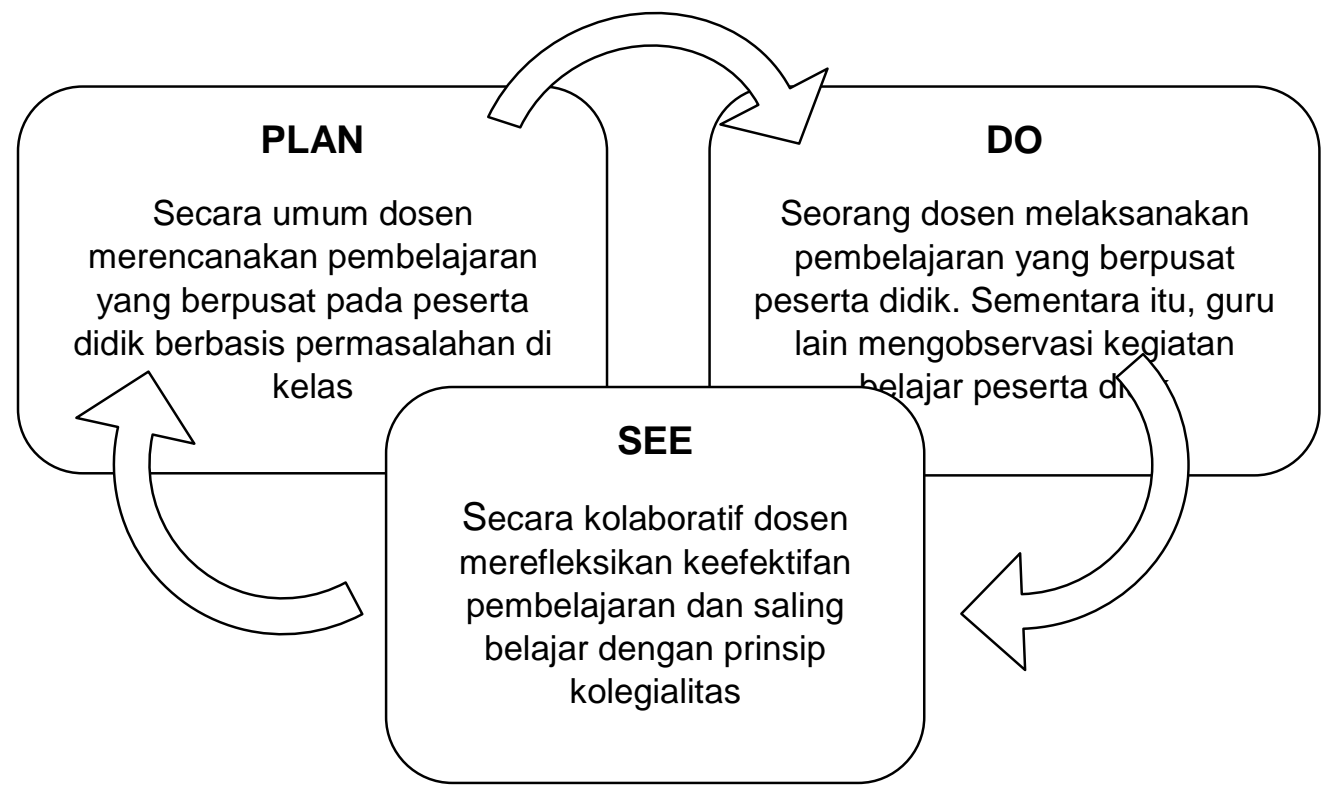

Dari gambar siklus tersebut, maka pelaksanaan Pembelajaran Sintaksis Bahasa Indonesia akan dilakukan sesuai dengan tahapan seperti yang tertera di atas

\section{Plan}

Pada tahap Plan atau merencanakan, dosen menyusun Rencana Pelaksanaan Pembelajaran dan silabus mata Kuliah
Sintasis Bahasa Indonesia sebagai acun dosen dalam melaksanakan pembelajaran. Dalam penyusunan RPS, dosen mengacu pada Capaian Pembelajaran SN-Dikti yang meliputi Aspek Sikap, Aspek Pengetahuan, Aspek Keterampilan Umum, dan Aspek Keterampilan Khusus lalu menyusun capaian pembelajaran program studi 
berdasarkan pada asosiasi program studi. Kemudian barulah diusun capaian pembelajaran mata kuliah sesuai dengan mata kuliah yang diampu. Dalam proses penyusunan RPS dan silabus, dosen pengampu mata kuliah meminta satu dosen lain tim program PDS untuk mencermati dan memberikan masukan mengenai perangkat pembelajaran mata kuliah Sintaksis Bahasa Indonesia yang dibuat, dengan maksud supaya perangkat pembelajaran yang dibuat atau disusun menjadi lebih baik lagi.

Pada tahap perencanaan, terlebih dahulu dosen melakukan analisis terlebih dahulu menge nai materi yang tepat dan cocok berdasarkan silabus dalam kurikulum yang ditetapkan untuk mahasiswa semester IV Program Studi Pendidikan Bahasa dan Sastra Indonesia dalam mata kuliah Sintaksis Bahasa Indonesia. Berdasarkan penyusunan capaian pembelajaran program studi dan capaian pembelajaran mata kuliah, maka disusunlah RPS dan Silabus sesuai dengan materi yang akan diajarkan.

Plan menurut Hendayana (2006:11) bertujuan menghasilkan rancangan pembelajaran yang dapat membelajarkan siswa yang efektif dan berpusat pada siswa, membangkitkan partisipasi siswa dalam pembelajaran.
Dalam penyusunan rencana pembelajaran harus dilakukan secara kolaboraif dengan dosen lain agar menghasilkan rencana pembelajaran yang baik. Oleh karena itu dalam penyusunan Rencana Pembelajaran Semester dilakukan secara kolaboratif dengan dosen lain yang linier keilmuannya. Pada saat penyusunan RPS, diminta beberapa dosen lain yakni dosen Program Studi Pendidikan Bahasa Inggris dan Pendidikan Matematika untuk memberikan masukan mengenai RPS yang sudah dibuat oleh dosen pengampu mata kuliah. Dari masukan dosen Program Studi Bahasa dan Sastra Indonesia, Program Studi Pendidikan Bahasa Inggris, dan Program Studi Pendidikan Matematika mengenai RPS yang dibuat jadi semakin baik memenuhi ketentuan yang berlaku dalam kurikulum.

Capaian Pembelajaran Program Studi Pendidikan Bahasa dan Sastra Indonesia alam mata kuliah Sintaksis Bahasa Indonesia yang mencakup Aspek Sikap, Aspek Pengetahuan, Aspek Keterampilan Umum, dan Aspek Keterampilan Khusus. Aspek Capaian Pembelajaran Program Studi disusun berdasarkan Asosiasi Program Studi dengan beberapa kali revisi yang 
mengacu pada Kurikulum KKNI Standar Nasional Pendidikan Tinggi.

Capaian Pembelajaran Prodi

\begin{tabular}{|c|c|}
\hline \multicolumn{2}{|r|}{ Capaian Pembelajaran Sikap dan Tata Nilai (ST) } \\
\hline 1. & bertagwa kepada Tuhan YME dan mampu menunjukan sikap religius; \\
\hline 2. & $\begin{array}{l}\text { menjunjujung tinggi nilai kemanusiaan dalam menjalankan tugas } \\
\text { berdasarkan agama, moral dan etika; }\end{array}$ \\
\hline 3. & $\begin{array}{l}\text { berkontribusi dalam peningkatan mutu kehidupan bermasyarakat, } \\
\text { bernegara dan kemajuan peradapan berdasarkan pancasila; berkontribusi } \\
\text { dalam peningkatan mutu kehidupan bermasyarakat, bernegara dan } \\
\text { kemajuan peradapan berdasarkan pancasila; }\end{array}$ \\
\hline 4. & berperan sebagai warga negara yag bangga dan cinta tanah air; \\
\hline 5. & $\begin{array}{l}\text { menghargai keanekaragaman budaya, pandangan, agama, kepercayaan } \\
\text { serta pendapat atau temuan orisinal orang lain; }\end{array}$ \\
\hline 6. & $\begin{array}{l}\text { bekerjasama dan memiliki kepekaan serta kepedulian terhadap masyarakat } \\
\text { dan lingkungan; }\end{array}$ \\
\hline 7. & taat hukum dan disiplin dalam kehidupan bermasyarakat dan bernegara; \\
\hline 8. & menginternalisasi nilai norma, dan etika akademik; \\
\hline 9. & $\begin{array}{l}\text { menunjukan sikap bertanggung jawab atas pekerjaan di bidang } \\
\text { keahliannya; }\end{array}$ \\
\hline 10. & $\begin{array}{l}\text { menginternalisasikan semangat kemandirian dan kejuangan } \\
\text { kewirausahaan; }\end{array}$ \\
\hline 11. & $\begin{array}{l}\text { menginternalisasikan misi persyarikatan Muhamadiyah dalam berbagai } \\
\text { aspek kehidupan; }\end{array}$ \\
\hline 12. & $\begin{array}{l}\text { menguasai dan mengintegrasikan nilai-nilai dalam pengembangan dan } \\
\text { penerapan ilmu pengetahuan; }\end{array}$ \\
\hline \multicolumn{2}{|r|}{ Capaian Pembelajaran dibidang umum/keterampilan umum (KU) } \\
\hline 1. & $\begin{array}{l}\text { mampu menerapkan pemikiran logis, kritis, sistematis dan inovatif dalam } \\
\text { konteks pengembangan atau mengimplementasikan ilmu pengetahuan dan } \\
\text { teknologi yang memperhatikan dan menerapkan nilai humaniora yang } \\
\text { sesuai dengan bidang keahliannya; }\end{array}$ \\
\hline 2. & mampu menunjukan kinerja mandiri, bermutu dan terukur; \\
\hline 3. & $\begin{array}{l}\text { mampu mengkaji implikasi pengembangan ilmu pengetahuan teknologi } \\
\text { yang memperhatikan dan menerapkan nilai humaniora sesuai dengan keahliannya } \\
\text { berdasarkan kaidah, tatacara, dan etika ilmiah dalam rangka menghasilkan solusi, } \\
\text { gagasan, desain atau kritik seni menyusun deskripsi saintifik hasil kerjanya dalam } \\
\text { bentuk skripsi atau laporan penelitian; }\end{array}$ \\
\hline 4. & $\begin{array}{l}\text { menyusun deskripsi saintifik dalam bentuk skripsi atau laporan tugas } \\
\text { akhir; }\end{array}$ \\
\hline 5. & $\begin{array}{l}\text { mampu mengambil keputusan secara tepat dalam konteks penyelesaian } \\
\text { masalah di bidang keahliannya berdasarkan hasil analisis data }\end{array}$ \\
\hline 6. & $\begin{array}{l}\text { mampu memelihara jaringan dan kerjasama dengan pembimbing, kolega } \\
\text { sejawat baik dalam lembaganya maupun di luar lembaganya }\end{array}$ \\
\hline 7. & $\begin{array}{l}\text { mampu bertanggung jawab atas pencapaian hasil kerja kelompok dan } \\
\text { melakukan supervisi dan evaluasi terhadap penyelesaian pekerjaan Yng } \\
\text { ditugaskan kepada pekerja yang berada di bawah tanggung jawabnya; }\end{array}$ \\
\hline 8. & $\begin{array}{l}\text { mampu melakukan proses evaluasi terhadap kelompok kerja yang } \\
\text { bertanggung jawab dan mampu mengelola pembelajaran swcara baik }\end{array}$ \\
\hline
\end{tabular}




\begin{tabular}{|c|c|}
\hline \multicolumn{2}{|r|}{ Capaian Pembelajaran di Bidang Kerja/ Keterampilan Khusus (KK) } \\
\hline 1. & $\begin{array}{l}\text { mampu menerapkan pemikiran logis, kritis, kreatif, dan inovatif dalam } \\
\text { pengembangan ilmu kebahasaan, ilmu sastra, ilmu pendidikan dan } \\
\text { keterampilan berbahasa serta pembelajaran bahasa dan sastra Indonesia } \\
\text { dengan cara konstruktif sehingga menemuksan solusi terhadap masalah } \\
\text { pembelajaran; }\end{array}$ \\
\hline 2. & $\begin{array}{l}\text { terampil berbahasa dan bersastra dengan metode resitasi sehingga mampu } \\
\text { menghasilkan makala, proposal penelitian, mengembangkan teknologi di } \\
\text { bidang kebahasaan }\end{array}$ \\
\hline 3. & $\begin{array}{l}\text { mampu mengkaji pengembangan atau implementasi pengetahuan dan } \\
\text { teknologi di bidang kebahasaan, kesasrraan, keterampilan, } \\
\text { kependidikandan pembelajaran bahasa dan sastra indonesia serta mampu } \\
\text { secara saintifik menghasilkan bentuk penelitian yang berwujud skripsi dan } \\
\text { artikel ilmiah }\end{array}$ \\
\hline 4. & $\begin{array}{l}\text { menyusun skripsi sesuai dengan pedoman penulisan yang ditentukan oleh } \\
\text { Perguruan Tinggi dan menulis artikel sesuai dengan gaya selingkung yang } \\
\text { telah ditetapkan oleh Prodi di Perguruan Tinggi }\end{array}$ \\
\hline 5. & $\begin{array}{l}\text { mengambil keputusan dalam suatu permasalahan kebahasaan, kesastraan, } \\
\text { keterampilan berbahasa, kependidikan, dan pembelajaran bahasa } \\
\text { Indonesia berdasarkan hasil analisis informasi dan data dengan cara } \\
\text { problem solving; }\end{array}$ \\
\hline 6. & $\begin{array}{l}\text { mampu memelihara dan mengembangkan jaringan kerja dengan lembaga } \\
\text { yang relevan, mengembangkan kerjasama dengan pembimbing, } \\
\text { mahasisw dan pimpinan melalui pendekatan komunikatif sehinggaterjalin kerjasama } \\
\text { yang harmonis di lingkungan kerja; }\end{array}$ \\
\hline 7. & $\begin{array}{l}\text { mampu bertanggung jawab terhadap hasil kerja kelompok dalam } \\
\text { prosespembelajaran, penyusunan karya ilmiah, dan menulis kreatif serta } \\
\text { melakukan refleksi terhadap hasil kerja yang dilakukan pekerja yang } \\
\text { berada di bawah tanggung jawabnya; }\end{array}$ \\
\hline 8. & $\begin{array}{l}\text { mampu mengadakan proses evaluasi diri terhadap kelompok kerja dengan } \\
\text { menerapkan pembelajaran lesson studi, manajemen sekolah dan mampu } \\
\text { mengelola pembelajaran secara mandiri. }\end{array}$ \\
\hline \multicolumn{2}{|r|}{ Capaian Pembelajaran di Bidang Pengetahuan (KP) } \\
\hline 1. & $\begin{array}{l}\text { mampu memahami konsep, teori, metode, dan filosofi linguistik, yang } \\
\text { meliputi fonologi, morfologi,sintaksis, semantik di bidang bahasa } \\
\text { Indonesia dan mampu menganalisis permasalahan kebahasaan yang } \\
\text { meliputi teks, wacana, kesalahan berbahasa dan penyuntingan; }\end{array}$ \\
\hline 2. & $\begin{array}{l}\text { terampil berbahasa dan bersastra dengan metode resitasi sehingga mampu } \\
\text { menghasilkan makalah, proposal penelitian, mengembangkan teknologi } \\
\text { di bidang kebahasaan, dan perangkat pembelajaran; }\end{array}$ \\
\hline 3. & mampu memahami konsep, teori, metode, filosofi keterampilan berbahasa; \\
\hline 4. & $\begin{array}{l}\text { mampu memahami konsep, teori, metode, dan filosofi kependidikan serta } \\
\text { mampu menganalisis permasalahan di bidang kependidikan; }\end{array}$ \\
\hline 5. & $\begin{array}{l}\text { mampu memahami konsep, teori, metode, dan filosofi pembelajaran serta } \\
\text { mampu menganalisis permasalahan di bidang pembelajaran yang } \\
\text { meliputikurikulum sekolah menengah, buku siswa dan buku guru sekolah } \\
\text { menengah, perencanaan pembelajaran', penilaian autentik, bahan ajar, } \\
\text { strategi/metode/ pendekatan pembelajaran, media dan alat pembelajaran } \\
\text { bahasa dan sastra Indonesia }\end{array}$ \\
\hline
\end{tabular}


Berdasarkan hasil Capaian

Pembelajaran Program Studi dan penentuan bahan kajian maka selanjutnya merumuskan Capaian pembelajaran mata kuliah. Capaian Pembelajaran mata kuliah turunan dari Capaian Pembelajaran Prodi dengan menyesuaikan materi ajar yang akan dibahas pada pertemuan tersebut.

\section{Pelaksanaan (Do)}

Pada tahap pelaksanaan yang dilakukan dalam pembelajaran mata kuliah Sintaksis Bahasa Indonesia pada mahasiswa semester empat sebanyak delapan kali pertemuan.Pelaksanaan pembelajaran yang dilakukan oleh dosen pengampu sesuai dengan tahapan-tahapan yang ada pada Rencana Pembelajaran Semester yang disusun/dibuat. Tahapan awal yang dilakukan oleh dosen dengan memberikan penjelasan mengenai strategi, metode, media, dan model pembelajaran, serta materi atau bahan kajian yang akan dibahas dalam mata kuliah tersebut.

\section{A. Pertemuan Pertama}

Pada pertemuan pertama dosen pengampu memaparkan mengenai materi yang akan dibahas dalam mata kuliah Sintaksis Bahasa Indonesia untuk Program Pendampingan Dosen di sekolah. Dosen pengampu memaparkan mengenai langkahlangkah yang harus dilakukan antara dosen dan mahasiswa dalam mata kuliah Sintaksis Bahasa Indonesia. Adapun langkah-langkahnya:

1) Dosen memaparkan materi definisi kalimat, kalimat tunggal, dan contoh, serta tujuan akhir yang akan dicapai dalam pembahasan materi,

2) Selanjutnya dosen menjelaskan pengertian kalimat dan kalimat inti secara singkat mengenai materi dan memberi kesempatan kepada mahasiswa untuk bertanya mengenai materi yang baru dipaparkan.

3) Dosen membagi kelompok mahasiswa dan mahasiswa diminta untuk mendiskusikan materi definisi kalimat dan kalimat inti.

4) Setiap Kelompok diminta untuk mempresentasikan hasil dari diskusi mengenai kalimat tunggal dan contohnya dan mahsiswa lain diminta untuk menanggapi hasil dari setiap kelompok.

5) Mahasiswa dan dosen menyimpulkan inti materi yang didiskusikan. 
6) Dosen memberi gambaran secara singkat untuk pembahasan materi berikutnya.

Pada pelaksanaannya dalam kelompok yang mendiskusikan materi mengenai kalimat tunggal dan menentukan fungsi kata pada kalimat tunggal tersebut. Dalam diskusi terlihat beberapa kelompok sangat antusias dalam diskusi dan berusa ingin tahu maksud dari pembahasann kalimat tunggal dan fungsi kata pada kalimat tunggal tersebut, tetapi ada dua kelompok, 3 mahasiswa dari kelompok tersebut masih sangat pasif dan belum termotivasi untuk mengetahui lebih dalam mengenai materi yang dibahas.Melihat kondisi tersebut, dosen pengampu melakukan pendekatan dan bimbingan terhadap mahasiswa yang belum termotivasi dan interaktif dalam diskusi. Setelah mahasiswa dalam diskusi mampu menyelesaikan materi yang didiskusikan, maka langkah selanjutnya dosen meminta kelompok mempresentasikan materi dan fungsi kata pada kalimat tersebut. Kelompok lain diminta untuk menanggapi hasil dari materi yang didiskusikan. Presentasi yang dilakukan oleh kelompok dalam pembahasan materi, banyak mahasiswa yang mengajukan pertanyaan dan mahasiswa kelompok lain menanggapi. Hal ini terlihat interaktif yang dilakukan antara mahasiswa dalam kelompok, dari kelompok satu ke kelompok lain sangat baik.

\section{B. Pertemuan Kedua dan ketiga}

Pada pertemuan kedua proses pembelajaran mata kuliah Sintaksis Bahasa Indonesia melanjutkan materi sebelumnya mengenai kalimat tunggal atau kalimat inti dan contoh kalimat tunggal serta penentuan fungsi kata pada kalimat.sebelum dilakukan lebih lanjut, dosen menjelaskan langkahlangkah dalam pembelajaran.

1) Dosen meminta mahasiswa memahami konsep kalimat tunggal dan fungsi kata kalimat tunggal tersebut.

2) Dosen meminta mahasiswa untuk membuat contoh kalimat tunggal dan menentukan fungsi kata pada kalimat.

3) Dosen memberi kesempatan kepada mahasiswa membuat contoh dan menentukan fungsi kata pada kalimat tunggal.

Proses pelaksanaan pembelajaran yang dilakukan oleh dosen pengampu pada mahasiswa menggunakan metode dan 
model pembelajaran yang bervarisi dan sesuai dengan karakteristik mahasiswa. Proses pembelajaran yang dilakukan oleh dosen pengampu memaparkan 10 kalimat dan mahasiswa diminta untuk menentukan fungsinya.

Dalam kelompok, mahasiswa sangat antusias untuk menunjukan dirinya dalam membuat contoh kalimat tunggal. Selain itu juga mahasiswa dalam kelompok berusaha untuk bisa menentukan fungsi kata pada kalimat seperta yang dipaparkan oleh dosen pengampu. Sebagai dosen pengampu mata kuliah memberi kesempatan kepada mahasiswa, jika mahasiswa mampu mengerjakan 5 kalimat dan menentukan fungsi kata dengan benar, dosen akan memberikan nilai tambah bagi mahasiswa atau minimalnya mendapatkan nilai B. Hal ini justru membuat mahasiswa tambah semakin bersemangat untuk lebih memahami konsep dan mampu mengimplementasikan konsep tersebut, dalam arti buat contoh kalimat dengan benar.

Pembelajaran dikatakan menyenangkan apabila didalamnya terdapat suasana rileks, bebas dari tekanan, aman, menarik, bangkitnya minat belajar, adanya keterlibatan penuh, perhatian peserta didik tercurah, lingkungan belajar yang menarik, adanya keterlibatan, bersemangat, perasaan gembira, konsentrasi tinggi. Begitu sebaliknya pembelajaran tidak menyenangkan jika terdapat suasana yang tidak menyenangkan, tidak menarik, tertekan, tidak ada minat belajar dll, (Indrawati dan Setiawan, 2009:24). Syaratsyarat yang diperlukan dalam mengajar dan membangun pembelajaran agar efektif dan saling bekerja sama dalam belajar supaya tercipta suasana yang menyenangkan dan saling menghargai diantaranya:

a) Guru harus lebih banyak menggunakan metode yang bervariasi yang mengakibatkan penyajian bahan lebih menarik perhatian mahasiswa dan mudah diterima sehingga kelas menjadi hidup.

b) Menumbuhkan motivasi, hal ini sangat berpengaruh pada perkembangan dan kemajuan mahasiswa. Selanjutnya melalui proses belajar, jika motivasi guru tepat dan mengenai sasaran akan meningkatkan hasil belajar mahasiswa (Jurnal Sosial Humaniora volume 5 no 2, November 2012)

Dari hasil pelaksanaan pembelajaran menunjukan bahwa pentingnya metode dan model pembelajaran yang bervariasi agar minat dan motivasi mahasiswa semakin tinggi dalam mengikuti pembelajaran terutama mata kuliah Sintaksis Bahasa Indonesia.

Tentu saja dalam proses pembelajaran dibutuhkan konsentrasi yang tinggi dan kondisi kelas yang nyaman. Oleh karena itu pengaturan lngkungan belajar sangat 
diperlukan agar mahasiswa mampu melakukan kontrol terhadap pemenuhan kebutuhan emosional. Lingkungan belajar yang demokratis memberi kebebasan kepada mahasiswa untuk melakukan pilihan tindakan belajar dan akan mendorong anak untuk terlibat secara fisik, emosional dan mental dalam proses pembelajaran, sehingga dapat memunculkan pembelajaran yang kreatif-produktif (Budiningsih, 2008:7)

\section{Pertemuan Ketiga dan keempat}

Pada pertemuan ketiga dan keempat pembelajaran yang dilakukan mahasiswa semester IV semakin bersemangat dan termotivasi mengikuti kegiatan dalam materi kalimat majemuk baik majemuk setara maupun kalimat majemuk bertingkat. Dalam proses pembelajaran ini menggunakan model pembelajaran snowball trowing. Proses pembelajaran diawali oleh dosen yang menjelaskan materi tentang kalimat majemuk dan jenis kalimat majemuk. Mahasiswa mendengarkan materi yang dijelaskan oleh dosen. Dosen memberi kesemapatan kepada mahasiswa untuk mengajukan pertanyaan terkait dengan materi yang dibahas. Dari proses yang terjadi antara dosen dan mahasiswa ada beberapa mahasiswa yang mengajukan pertanyaan yang berkaitan dengan kalimat majemuk setara dan kalimat majemuk bertingkat, pertanyaan yang dikemukakan adalah "Bagaimana membedakan antara kalimat majemuk setara dan kalimat majemuk bertingkat"?. Lalu dosen menjelaskan perbedaan tersebut, untuk mempermudah pemahaman mahasiswa, dosen memberi contoh. Setelah penjelasan dan kesempatan bertanya yang diberikan kepada mahasiswa, lalu dosen meminta mahasiswa secara berkelompok untuk mendiskusikan materi tersebut.

Kegiatan diskusi dilaksnakan oleh mahasiswa, dalam diskusi terlihat mahasiswapun dapat bekerja sama dengan baik mengenai materi yang dibahas, bahkan ada mahasiswa yang belum pahampun diajari oleh mahasiswa yang memiliki kemampuan lebih. Kerjasama mahasiswa sangat diperjuangkan dan dipertahankan untuk bisa mempresentasikan hasil materi yang didiskusikan. Begitu pula terlihat juga dengan kelompok lain. Kemudian presntasi dari kelompok dilakukan, kelompok lain mengajukan pertanyaan dan menanggapi hasil dari materi yang didiskusikan.

Setelah kegiatan diskusi dan presentasi selesai, dosen memberi tugas kepada mahasiswa dalam kelompok terkait dengan materi yang sudah dibahas. Dosen meminta mahasiswa dalam kelompok untuk membuat pertanyaan yang kemudian pertanyaan tersebut digulung seperti bentuk bola yang diberikan kepada kelompok lain. Kelompok lain yang mendapat lemparan gulungan bola, maka kelompok tersebutlah 
yang akan menjawab pertanyaan. Pembelajaran yang menyenangkan dengan melalui permainan ini membuat mahasiswa justru semakin bersemangat dan antusias untuk memahami konsep dan penerapan dalam materi tersebut.

Ada pakar yang mengatakan bahwa dalam proses pembelajaran yang menyenangkan jika dalam pembelajaran,

1) tetap berorientasi pada tujuan pembelajaran

2) melibatkan mahasiswa dalam pembelajaran

3) pembelajaran berpusat pada siswa/mahasiswa

4) menyeimbangkan aspek kognitif, afektif dan psikomortorik

5) pembelajaran jadi bermakna

6) membuat siswa/mahasiswa untuk selalu bersemangat mengikuti pembelajaran

7) menggunakan metode, teknik, model pembelajaran yang bervariatif

(Guru yang menyenangkan (https://www.rijal109.com Artikel Pembelajaran yang Menyenangkan 1 Maret 2017)

Pembelajaran yang menyenangkan, jika mahasiswa mengalami sendiri, terjadi interaksi anatara mahasiswa dan dosen, dan terjadi komunikasi yang menyenanngkan dari mahsiswa dalam kelompok. Adapun karakteristik pembelajaran yang menyenangkan maka harus terfokus kepada mahasiswa.

1) Mengalami, maksudnya mahasiswa mengalami sendiri, misalnya melakukan pengamatan, membaca, melakukan percobaan, penyelidikan, dll.

2) Komunikasi, maksudnya mahasiswa dapat mengemukakkan pendapat, presentasi, ungkap gagasan, memajangkan hasil kerja.

3) Interaksi, maksudnya mahasiswa dapat berinteraksi melalui diskusi kelompok, tanya jawab, lempar pertanyaan dll.

4) Refleksi, maksudnya mengingat kembali apa yang sudah dibahas atau didiskusikan mengenai materi. Melalui refleksi akan diketahui seberapa banyak konsep/teori yang dipahami dan bagaimana menerapkannya. Dari karakteristik tersebut, bahwa pembelajaran lebih terpusat kepada mahasiswa dan bagaiman mahasiswa tersebut belajar untuk memperoleh pengetahuan dan pengalaman melalui pembelajaran yang dilaksnakan di kelas.

https://Suadinmath.wordspress.com./20 13/02/09/Pentingnya-Pembelajaranmenyenangkan-dalam-peningkatan mutu-proses-dan hasil-belajar sebuah artikel) 


\section{Pertemuan kelima-Keenam}

Pada pertemuan berikut pembelajaran yang dilakukan di kelas semester IV semakin baik dengan menggunakan metode dan model pembelajaran yang bervariasi. Dengan menggunakan model dan metode yang bervariasi semakin termotivasi dan semangat dalam mengikuti pembelajaran. Mahasiswa berkeinginan untuk bertanya, menanggapi, mengemukakkan pendapat.

Hal ini mahasiswa mampu menguasai konsep dan mampu menerapkan sesuai dengan materi yang dibahas. Pada pertemuan ini mahasiswa secara kelompok mempresentasikan materi terkait dengan kalimat efektif. Masing-masing kelompok mempresentasikan dan mahasiswa lain menanya dan menanggapi terkait dengan materi yang dibahas. Pada akhir pertemuan, dosen bersama mahasiswa menyimpulkan inti materi yang dibahas.

Para dosen hendaknya menyadari bahwa pembelajaran yang menyenangkan dapat meningkatkan keberhasilan dalam proses pembelajaran. Oleh karena itu, hendaknya dosen mampu menciptakan suasana yang menyenangkan dalam setiap proses pembelajaran. Beberapa cara yang dapat dipakai oleh dosen dalam menciptakan pembelajaran yang menyenangkan, diantaranya menggunakan metode dan model pembelajaran yang bervariasi, menggunakan ice breaking, suasana rilek, dan menyapa peserta dengan hangat dan menciptakan suasana yang rileks.

\section{E.Pertemuan Ketujuh-delapan}

Pertemuan ini diawali dengan melakukan apersebsi mengenai materi yang dibahas pada pertemuan yang lalu, dengan mengajukan pertanyaan kepada beberapa mahasiswa, apersebsi dilakukan untuk mengetahui penguasan konsep dan implementasi materi yang dikuasai. Pada pertemuan ini dosen memaparkan langkahlangkah mengenai proses pembelajaran Proses pembelajaran ini juga menggunakan metode dan model bervariasi yakni metode membaca dan meulis serta menggunakan model jigsaw. Adapun langkah-langkah model jigsaw adalah (1) mahasiswa berkelompok 5-6 orang, (2) mahasiswa mengerjakan/membahas masalah yang berbeda, (3) mahasiswa dalam kelompok melaporkan hasil diskusi dengan mempresentasikan hasilnya, (4) satu mahasiswa ditunjuk untuk mempresentasikan hasilnya, (5) mahasiswa dan dosen menyimpulkan hasil dari diskusi. Dalam prosesnya secara kelompok, mahasiswa memecahkan permasalahan yang berkaitan dengan "Masalah dan pemecahannya dalam Sintaksis Bahasa Indonesia". Masing-masing kelompok mengerjakan tugas yang berbeda tetapi tetap mengacu pada masalah tersebut. Hal ini yang membuat mahasiswa secara kelompok mampu memecahkan 
permasalahan dengan baik dan terlihat sekali kerja sama antaranggota dalam kelompok, kelompok satu dengan kelompok lain. Keingintahuan mahasiswa tentang materi yang dibahas, banyak sekali mahasiswa dalam kelompok yang mengajukan pertanyaan kepada dosen pengampu. Dosen pengampu mengarahkan dan membimbing mahasiswa dalam memecahkan permasalahan yang dibahas. Hal ini terlihat bahwa dalam proses pembelajaran tersebut bersifat demokratis, terbuka, dan berkelanjutan. Demokratis artinya mahasiswa deberikan haknya sebagai mahasiswa maksudnya mahasiswa diberi kesempatan untuk bertanya, menanggapi, dan mengemukakan pendapat mengenai materi yang dibahas. Jadi dalam hal ini bukan saja mahasiswa belajar tetapi juga dosen belajar untuk mendapatkan pengetahuan dan pengalaman. Dosen memberikan haknya kepada mahasiswa untuk dapat mengembangkan sesuai kemampuan yang dimilikinya. Bersifat terbuka yang dimaksudkan dosen bisa memberi kesempatan kepada dosen lain atau teman sejawat untuk mengamati proses pembelajaran yang dilaksanakan. Jadi bukan mutlak otoritas dosen pengampu. Kemudian bersifat berkelanjutan maksudnya dosen pengampu akan selalu melakukan perbaikan guna peningkatan kualitas pembelajaran dalam dunia pendidikan. Dosen pengampu mampu melakukan perbaikan pembelajaran berdasarkan hasil pembelajaran yang sudah dilaksanakan (Makalah Pelatihan PEKERTI:2017). Dengan melihat hasil yang dilaksanakan dalam proses pembelajaran, mahasiswa dapat mengembangkan segala potensi yang dimiliki dan akan meningkatkan wawasan dan pengetahuannya dari tidak tahu menjadi tahu. Pendidikan berusaha dan berupaya menjadi wadah dalam pengembangan dan peningkatan pengetahuan dan wawasan mahasiswa.

\section{Refleksi (See)}

Refleksi Pembelajaran adalah suatu komponen kegiatan yang dilaksanakan setelah proses pembelajaran berlangsung dengan tujuan untuk mengamati dan menilai setelah melakukan pembelajaran. Proses pembelajaran Sintaksis Bahasa Indonesia pada mahasiswa semester IV melalui perekaman vidio dan tanya jawab. Dalam proses pembelajaran melalui perekaman dan tanya jawab ditemukan ada beberapa mahasiswa, kira-kira $12 \%$ dalam kelompok belum sepenuhnya menguasai konsep sehingga kesulitan untuk mempraktikan cara membuat dan memperbaiki kalimat tidak efektif menjadi kalimat efektif. Sementara yang $88 \%$ sudah aktif, kreatif, dan antusias mengikuti proses pembelajaran.Berdasarkan hasil temuan tersebut dosen pengampu melakukan tindak 
lanjut terhadap $12 \%$ mahasiswa yang kesulitan dalam menguasai konsep serta menerapkan konsep. Melalui bimbingan langsung dari dosen pengampu dalam pembelajaran Sintaksis Bahasa Indonesia akan semakin baik.

\section{PENUTUP}

\section{Simpulan}

Hasil menunjukan bahwa dalam proses pembelajaran mata kuliah Sintaksis Bahasa Indonesia menunjukan bahwa mahasiswa sebanyak $88 \%$ persen sangat aktif, kreatif, dan antusias mengikuti proses pembelajaran. Dengan menggunakan metode dan model pembelajaran yang bervariasi sehingga banyak mahasiswa yang mengajukan pertanyaan, tanggapan, dan mengemukakan pendapat mengenai materi yang dibahas. Selain itu juga proses pembelajaran bersifat demokratis dan terbuka yang lebih berpusat pada mahasiswa. Melalui bentuk pembelajaran yang membuat mahasiswa semakin aktif dan kreatif serta antusias dalam mengikuti pembelajaran. Jadi melalui Program Penugasan Dosen Di Sekolah dapat (1) meningkatkan kompetensi dosen dan meningkatkan kemampuan mahasiswa dalam bidang ilmu yang dipelajari, (2) menciptakan pembelajaran yang bermutu dengan indikator terciptanya iklim pembelajaran yang semakin baik, menghasilkan perangkat pembelajaran yang bermutu. Melalalui Kegiatan Penugasan Dosen di Sekolah mampu menciptakan pembelajaran yang bermutu dengan indikator terciptanya iklim pembelajaran yang semakin baik, perangkat pembelajaran yang berkualitas dan meningkatkan mutu/kua litas pembelajaran mahasiswa.

2. Saran

1. Dapat digunakan oleh guru/dosen dalam menciptakan pembelajaran yang menyenangkan bagi peserta didik atau mahasiswa

2. Menghasilkan Perangkat Pembelajaran yang bermutu atau berkualitas

\section{DAFTAR PUSTAKA}

Asri, Budingsih C.2008. Belajar Pembelajaran. Jakarta: Budi Aksara Cahyo, A.N.2013. Panduan Aplikasi Teori Belajar Mengajar. Jokyakarta:Diva Press

Djamarah, S.B.2008. Strategi Belajar mengajar. Bandung: Rineka Cipta 
Hendayana, dkk. 2006. Lesson Study Suatu Strategi Untuk Meningkatakan Keprofesionalan Pendidik (Pengalaman IMSTEP-JICA). Bandung: UPI Press

https://Suadinmath.wordspress.com/2013/02/09/Pentingnya Pembelajaran Menyenangkan dalam Peningkatan Mutu Proses dan Hasil Belajar

https://www.rijal109.com . Artikel Pembelajaran yang Menyenangkan 1 Maret 2017)

Indrawati dan Wawan Setiawan.2009. Modul Pembelajaran Aktif, Kreatif, Efektif, dan Menyenangkan.PPPTKI PA Jurnal Sosial Humaniora volume 5 no 2, November 2012

Makalah Lesson Study disampaikan dalam Pelatihan Pengembangan Keterampilan Teknik Instruksional (PEKERTI). Universitas Muhammadiyah Metro selama 4-8 Januari 2017

Materi Pelatihan Implementasi Kur ikulum 2013 Tahun 2016. Kemendikbud.

Sentana. K, Septiawan. 2010. Menulis Ilmiah Metodologi Penelitian Kualitatif Edisis Kedua. Jakarta: Yayasan Pustaka Obor Indonesia

Sugiyono. 2011. Metode Penelitian Kuantitatif, Kualitataif, dan R\&D. Bandung: Alfabeta

Susilo, Herawati. 2011. Lesson Study Berbasis sekolah, Guru Konservatf Menuju Guru Inovatif. Malang: Bayu Media Publihing.

Perpres Nomor 8 Tahun 2012 Keranga Kualifikasi Nasional Indonesia

Permenristekdikti No. 44 Tahun 2015 tentang Standar Nasional Pendidikan Tinggi. 